\title{
Assessment of the content of arsenic in solid by-products from coal combustion
}

\author{
Faustyna Wierońska ${ }^{1, *}$, Dorota Makowska ${ }^{1}$ and Andrzej Strugała ${ }^{1}$ \\ ${ }^{1}$ AGH University of Science and Technology, Faculty of Energy and Fuels, Al. A. Mickiewicza 30, \\ 30-059 Krakow, Poland
}

\begin{abstract}
The coal combustion processes constitute one of the major sources of heavy metals emission into the atmosphere. From the point of view of the reduction of the emission of heavy metals and the selection of the correct exhaust gas treatment system, it is important to monitor the amount of trace elements in the solid fuels and in the solid by-products from coal combustion. One of these highly toxic elements is arsenic. The average content of arsenic in Polish hard coals and lignites is $0 \div 40 \mathrm{mg} / \mathrm{kg}$ [1] and $5 \div 15 \mathrm{mg} / \mathrm{kg}$ [2], respectively. The world average content of arsenic in hard coals and lignites, is equal to $9.0 \pm 0.8$ and $7.4 \pm 1.4 \mathrm{mg} / \mathrm{kg}$ [3], respectively. During coal combustion processes, a significant amount of arsenic enters the atmosphere through gases and fly ashes. The proportions in which those two forms of arsenic occur in exhaust gases depend on the conditions of combustion processes [4]. The aim of the research was to determine the content of arsenic in coal blends and by-products of their combustion (slag, fly ash, gypsum, filter cakes). The determination of the arsenic quantity was performed using the Atomic Absorption Spectrometry with the electrothermal atomization.
\end{abstract}

\section{Introduction}

During the year in Poland the consumption of hard coal reaches about 72,8 million tons, nearly $60 \%$ of which is connected with the energy sector [5]. The growing demand for energy can increase the release of large amounts of toxic elements and their compounds into the atmosphere. A reduction in emissions of these elements and compounds into the environment is achieved in exploited installations through the use of different flue gas treatment systems (the post-combustion methods). In domestic conditions there are installations for catalytic reduction of NOx, installations for desulfurization and systems for the removal of fly ashes, such as the electrostatic precipitator and the bag filters. Apart from the application of flue gas treatment systems, modern coal combustion technologies including pulverized coal combustion, fluidized bed combustion system or supercritical and ultra-supercritical technologies also have an impact on the emission of toxic elements [6].

One of the more toxic elements is arsenic. In Poland, during the combustion processes in the sector of production and transformation of energy, more than $4.8 \mathrm{Mg}$ of arsenic

\footnotetext{
* Corresponding author: wieronsk@agh.edu.pl
} 
and its compounds are emitted annually [7]. From the point of view of the environmental impact, this element belongs to the group of the most toxic elements together with cadmium, lead, mercury and chromium. It also belongs to the highly volatile elements in respect of coal combustion processes [8]. Arsenic has a negative impact on living organisms. It causes, among others, nervous system disorders, heart functions disorder or hepatic impairment. It is also regarded by the International Agency for Research on Cancer as a carcinogenic element $[9,10]$.

In coal arsenic is associated primarily with pyrite As- $\mathrm{S}_{\text {pyr. }}$. The average content of this element in Polish hard coals and lignites is $0 \div 40 \mathrm{mg} / \mathrm{kg}$ [1] and $5 \div 15 \mathrm{mg} / \mathrm{kg}$ [2], respectively. Additionally, the world average content of arsenic in hard coals and lignites, is equal to $9.0 \pm 0.8$ and $7.4 \pm 1.4 \mathrm{mg} / \mathrm{kg}$, respectively [3]. During coal combustion processes, arsenic bound to pyrite $\mathrm{As}-\mathrm{S}_{\mathrm{pyr}}$ and arsenic occurring in organic compounds $\mathrm{As}_{\text {org }}$ enter the exhaust gases through gases and fly ashes. The proportions of those two forms of arsenic are different and depend on the conditions of combustion processes. Arsenic associated with clay remains in the bottom ash $[3,4,11]$. The relationship between the content of As in coal and the amount of ash has been well described [3]. It can be concluded that coal with a higher ash content has a higher concentration of arsenic. Moreover, it has been proven that with the reduction of the particle diameter of fly ash, the content of As grows.

The highest contents of the discussed element were recorded also in the fly ash containing large amounts of magnesium and calcium. Therefore, in order to reduce the emissions of arsenic, sorbents based on calcium oxide are considered [12]. Arsenic located in the fly ash is almost totally removed from the exhaust gases using the electrostatic precipitator and the bag filters $[3,4,12,13]$. The concentration of As in the fly ash depends strictly on the initial content of this element in coal. The world average content of arsenic in the fly ash from hard coal is $46 \pm 5 \mathrm{mg} / \mathrm{kg}$ [14], but this value can fluctuate in very wide ranges even within one coal basin. In the case of coals from the Upper Silesian Coal Basin, the As content may range from 3 to $190 \mathrm{mg} / \mathrm{kg}$ [15]. Research [15] has shown, that the highest As content is associated with the smallest fly ash particles (with diameter below $20 \mu \mathrm{m}$ ).

In view of the negative effects of arsenic on the environment, it is important to know the content of this element in the solid by-products of coal combustion, owing to their usage (fly ash, gypsum) or storage (ash-slag). The amount of As in these products depends not only on the burnt coal, but also on the type of furnace and the flue gas treatment system. The investigations carried out within the framework of this study aimed at determining the content of the discussed element in the solid by-products of coal combustion in power plants.

\section{Experimental}

\subsection{Examined material}

The samples of coal blends burnt in the boilers and solid by-products of their combustion, i.e.: the average daily samples of fly ashes, ash-slag samples and products of desulphurization (gypsum and filter cakes) were analyzed. The examined samples came from two Polish fossil fuel power plants, which use thermal hard coal blends for combustion. Both plants use the same flue gas treatment system consisting of Selective Catalytic Reduction (SCR) to reduce the level of NOx, an Electrostatic Precipitator (ESP) and the Flue Gas Desulphurization (FGD) based on the wet lime method. In both cases, for the purposes of combustion, the Pulverized Coal Fired Boilers fired by coal coming 
from different mines of the Upper Silesian Coal Basin, are installed. In the analyzed samples the content of the elements: $\mathrm{Si}, \mathrm{Al}, \mathrm{Ca}, \mathrm{Fe}, \mathrm{Mg}, \mathrm{Na}$ and $\mathrm{K}$ was investigated (tables 1 and 2).

Table 1. The amount of $\mathrm{Si}, \mathrm{Al}, \mathrm{Ca}, \mathrm{K}, \mathrm{Na}, \mathrm{Mg}$ and $\mathrm{Fe}$ in examined samples [\%] - Power Plant 1.

\begin{tabular}{|c|c|c|c|c|c|c|c|}
\hline \multirow{2}{*}{ Sample } & \multicolumn{7}{|c|}{ Content of the elements [\%] } \\
\cline { 2 - 8 } & $\mathrm{Si}$ & $\mathrm{Al}$ & $\mathrm{Ca}$ & $\mathrm{K}$ & $\mathrm{Na}$ & $\mathrm{Mg}$ & $\mathrm{Fe}$ \\
\hline Coal & 5.68 & 1.98 & 0.53 & 0.53 & 0.20 & 0.38 & 1.24 \\
\hline Ash-slag & 18.31 & 10.10 & 2.71 & 2.24 & 0.41 & 1.65 & 6.27 \\
\hline Fly ash & 20.31 & 11.19 & 2.47 & 2.48 & 0.48 & 1.61 & 4.31 \\
\hline Gypsum & 0.275 & 0.061 & - & 0.019 & 0.003 & 0.035 & 0.044 \\
\hline Filter cake & 6.18 & 2.27 & 15.88 & 0.76 & 0.11 & 0.80 & 1.47 \\
\hline
\end{tabular}

Table 2. The amount of $\mathrm{Si}, \mathrm{Al}, \mathrm{Ca}, \mathrm{K}, \mathrm{Na}, \mathrm{Mg}$ and Fe in examined samples [\%] - Power Plant 2.

\begin{tabular}{|c|c|c|c|c|c|c|c|}
\hline \multirow{2}{*}{ Sample } & \multicolumn{7}{|c|}{ Content of the elements [\%] } \\
\cline { 2 - 8 } & $\mathrm{Si}$ & $\mathrm{Al}$ & $\mathrm{Ca}$ & $\mathrm{K}$ & $\mathrm{Na}$ & $\mathrm{Mg}$ & $\mathrm{Fe}$ \\
\hline Coal & 4.80 & 1.76 & 0.50 & 0.36 & 0.16 & 0.29 & 1.15 \\
\hline Ash-slag & 20.86 & 8.80 & 1.99 & 1.79 & 0.49 & 1.22 & 6.88 \\
\hline Fly ash & 17.20 & 9.34 & 2.54 & 1.98 & 1.31 & 1.48 & 6.14 \\
\hline Gypsum & 0.296 & 0.052 & - & 0.015 & 0.005 & 0.014 & 0.037 \\
\hline Filter cake & 5.69 & 1.99 & 16.40 & 0.79 & 0.10 & 0.94 & 2.37 \\
\hline
\end{tabular}

\subsection{Analytical methods}

The samples were prepared in accordance with the Polish standard PN-G-04502:2014-11. For coal samples, the determination of ash content in analytical conditions was executed in accordance with the standard PN-G-04512:1980/Az1:2002. For all samples, the determination of the chemical elements $\mathrm{Si}, \mathrm{Al}, \mathrm{Ca}, \mathrm{Fe}, \mathrm{Mg}, \mathrm{Na}$ and $\mathrm{K}$ was carried out using Atomic Absorption Spectrometry with flame atomization (FAAS). The content of arsenic in all samples was determined with the application of Graphite Furnace Atomic Absorption Spectrometer (GFAAS) Hitachi Z-2000 using the Zeeman background correction effect. The applied method was featured by the following analytical parameters: analytical spectral line 193,7 nm; flow of argon: $200 \mathrm{~cm}^{3} / \mathrm{min}$ (atomization $-30 \mathrm{~cm}^{3} / \mathrm{min}$ ); modifiers: Ni and Mg solution. The uncertainty of the As content $\pm 0.26 \mathrm{mg} / \mathrm{kg}$, was used.

In order to perform the analyses with the use of AAS, all samples were digested in the Berghoff SpeedWave4 microwave system. Nearly $130 \mathrm{mg}$ of sample was mineralized with the combination of spectrally pure nitric acid (V) and hydrofluoric acid. Subsequently, supersaturated boric acid was used as the complexing reagent. 


\section{Results and discussion}

The results of the investigations of the average arsenic content in samples of hard coal blends and in the solid by-products of their combustion were collected in table 3 . The concentration of As in coal, in the case of both power plants, was lower than the world average content of arsenic in hard coals $(9.0 \pm 0.8 \mathrm{mg} / \mathrm{kg})$. Accordingly, these coals can be classified as the ones with a low content of arsenic.

Table 3. The amount of arsenic in examined samples $\left[\mathrm{mg}_{\mathrm{As}} / \mathrm{kg}_{\text {sample }}\right]$.

\begin{tabular}{|c|c|c|}
\hline Sample & Power Plant 1 & Power Plant 2 \\
\hline Coal & 5.10 & 2.29 \\
\hline Ash-slag & 14.15 & 1.63 \\
\hline Fly ash & 28.21 & 12.46 \\
\hline Gypsum & 1.51 & 0.68 \\
\hline Filter cake & 25.60 & 28.06 \\
\hline
\end{tabular}

The ash content in coal derived from the first power plant was $21.7 \%$, and from the second power plant it was $11.1 \%$. It can be observed that a nearly twofold higher concentration of As in coal was determined for the sample with a higher ash content. The obtained result confirms the trend of the arsenic content towards growing along with the increasing ash content in coal. On the one hand, fly ashes and filter cakes are characterized by the highest content of this element on the other hand, the lowest concentration is displayed by the samples of gypsum (table 3). It was also observed that the ratio of the As content in fly ash and gypsum to the amount of this element in coal blends for both power plants is the same and amounts to: 5.5 for fly ash and 0.3 for gypsum. However, in the case of ash-slags and filter cakes, a similar relationship was not recorded. The content of As in filter cakes is similar. For the first and the second power plant this amount of As is $25.6 \mathrm{mg} / \mathrm{kg}$ and $28.1 \mathrm{mg} / \mathrm{kg}$, respectively. This provides evidence, that the examined element is accumulated in those wastes. It can be connected with the easy arsenic leaching by water and the accumulation in waste filtration as well as the presence of large amounts of calcium in the analyzed filter cakes (table 1 and 2) $[3,12]$. The larger arsenic content in ash-slag from the first power plant can also result from an increased calcium and magnesium content when compared to the second power plant.

\section{Conclusions}

The goal of this study was to examine the amount of arsenic in hard coal and solid by-products from coal combustion. Based on the investigations, the following conclusions can be drawn:

- The content of As in the analyzed samples is lower than the world average content of As in hard coals $(9.0 \pm 0.8 \mathrm{mg} / \mathrm{kg})$.

- The relationship between the content of As in coal and the ash content was confirmed. Along with the increase of ash content, the amount of As in coal grows.

- Arsenic accumulates mostly in fly ash and filter cakes.

- The gypsum samples are characterized by the lowest concentration of arsenic.

Acknowledgements: This paper was prepared as a part of the statutory activity of the Faculty of Energy and Fuels at the AGH University of Science and Technology, No. 11.11.210.213. 


\section{References}

1. J. Widawska-Kuśmierska, Występowanie pierwiastków śladowych w polskich węglach kamiennych, Przegląd Górniczy, nr 7-8, s. 455-459 (1981)

2. M. Wagnar, Oznaczenie pierwiastków toksycznych i szkodliwych w węglu i jego popiele, [w:] Eksploatacja węgla brunatnego jako metoda ograniczania szkodliwego oddziaływania na środowisko pierwiastków obecnych w węglu i w produktach jego spalania (na przykaładzie KWB Bełchatów) - Monografia, pod red. M. Stryszewski, Katedra Górnictwa Odkrywkowego, Wydział Górniczy AGH, Kraków (2001)

3. Ya.E. Yudovich, M.P. Ketris, Arsenic in coal: a review, International Journal of Coal Geology 61, p.141- 196 (2005)

4. V.C Pandey et al., Arsenic hazards in coal fly ash and its fate in Indian scenario, Resources, Conservation and Recycling Volume 55, Issues 9-10 p.819-835 (2011)

5. GUS, Główny Urząd Statystyczny, Zużycie Paliw i Nośników Energii w 2014 roku, Warszawa (2015)

6. U. Lorenz, Skutki spalania węgla kamiennego dla środowiska przyrodniczego i możliwości ich ograniczania, Mat. Szkoły Eksploatacji Podziemnej. Sympozja I Konferencje nr 64., Instytut GSMiE PAN, Kraków, s. 97-112 (2005)

7. KOBiZE, Krajowy Bilans Emisji $\mathrm{SO}_{2}, \mathrm{NOx}, \mathrm{CO}, \mathrm{NH}_{3}, \mathrm{NMLZO}$, pyłów, metali ciężkich i TZO za lata 2013 - 2014 w układzie klasyfikacji SNAP I NFR, Warszawa (2016)

8. K. Srogi, Pierwiastki śladowe w węglu, Wiadomości Górnicze 2/2007, s. 87-96

9. IARC MONOGRAPHS, Arsenic, Metals, Fibres and Dusts, vol.100C, s. 41-93 (2012)

10. E. Gawęda, Arsen i jego związki w środowisku pracy - zagrożenia, ocena narażenia, Bezpieczeństwo Pracy 3/2005, s 26-28

11. J. M. Pacyna, Lead, Mercury, Cadmium and Arsenic in the Environment: chapter 7: Atmospheric Emissions of Arsenic, Cadmium, Lead and Mercury from High Temperature Processes in Power Generation and Industry, SCOPE 31, SCOPE (1987)

12. R.M. Bolanz, J. Majzlan, L. Jurkovic, J. Göttlicher, Mineralogy, geochemistry, and arsenic speciation in coal combustion waste from Nováky, Slovakia, Fuel 94 s. $125-136$ (2012)

13. H. Nalbandian, Trace element emissions from coal, IEA Clean Coal Centre (2012)

14. M.P. Ketris, Ya.E. Yudovich, Estimations of Clarkes for Carbonaceous biolithes: World averages for trace element contents in black shales and coals. International Journal of Coal Geology, 78, pp. 135-148 (2009)

15. H.R. Parzentny, L. Róg, Potentially hazardous trace elements in ash from combusiton of coals in limnic series (Upper Carboniferous) of the Upper Silesian Coal Basin (USCB), Górnictwo i geologia, t. 2, z. 3, s. 81-91 (2007) 